\title{
THE SECURITIES TRANSFER ACT- \\ THE Radical RECONCEPTUALIZATION OF PROPERTY RIGHTS IN INVESTMENT SECURITIES
}

\author{
MOHAMEd F. KHIMJi
}

The Securities Transfer Act (STA), which came inlo force in Alberfa and Ontario on / Jamiary 2007. is based on the U.S. Unilorm Commercial Cods Revised Article 8 and reflects a radical reconceptualizatom of propern law regarding investment securities. This article analyzes the conceptual and policy choices behind the STA. focusing on the legislation's functional approach with respect to defining assets held by investors who hold securities through intermediaries, the property rights of such holders, cross-border sentemen conflict oflow rules. security inferests investment property: and conveyancing riles.

This article also responds to conceptual and policybased criticisms directed at the legislative model employed by the STA. The author argwes that the STA 's functional approach nevertheless significamly' contributes to a more accurate conceptual understanding of property rights in relation 10 intangible assets. Also, claims that property rights of prior holders are profected inodequately arc analyzed and discussed.
La loi str les transferts des titres (Securitics Transfer Act (STA)), entrée en vigueur en Alberta et en Ontario le I' janvicr 2007, esi basee sur l'article 8 revisé du Code commercial uniforme américuin, et reflète une nouvedle construction abstraite radicale du droit des biens en ce qui concerne les placements en valeurs mobilières. Cet article analyse les choix conceptuels et politiques derrière celle loi, en insistant sur l'approche fonctionmelle de la legislation en ce qui concerne la difinition des actifs des investisseurs qui possedent des valeurs mobilieres par des intermediaires, des droits de proprichi de ces détenteurs. le règlement Iransfrontalier de conflit de règles de droit, les biens de placement de süreté et les règles de transfert.

Cet article reiagit aussi anx criliques conceptmelles et fondees sur la politique adressies au modele législatif urilise' par la loi. L'aucur prèlend que l'approche fonctionnelle de la loi contribue néanmoins considérablement à une compréhension conceptuelle exacte' de droit des biens à l'igard des actifs intangibles. Dephus, les revendicutions àl effer que les droils des biens de ditenteurs antierieurs son mal proteges y som analysees et discuties.

\section{TABLE OF CONTENTS}

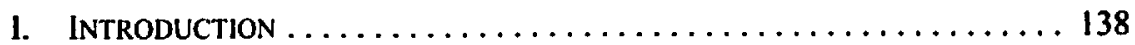

II. Modern Securities Settlement Practice $\ldots \ldots \ldots \ldots \ldots \ldots \ldots, 140$

A. The Traditional DiRect Holding System $\ldots \ldots \ldots \ldots \ldots, 140$

B. TIFE MODERN INDIRECT HOL.DING SYSTEM $\ldots \ldots \ldots \ldots \ldots \ldots 141$

III. BACKGROUND TO THE UNIFORM SECURITIES

TRANSFER ACT PROJECT . . . . . . . . . . . . . . . . . . . . 143

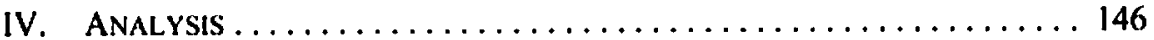

A. THE NATURE Of ThE INVESTOR'S ASSET $\ldots \ldots \ldots \ldots \ldots \ldots 147$

B. THE NATURE OF THE INVESTOR'S RIGHTS IN THE ASSET ....... 153

C. CONFLICT OF LAWS IN CROSS-BORDER SETTLEMENT ........ 155

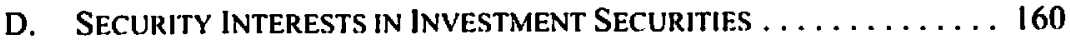

E. Priorities ................................ 163

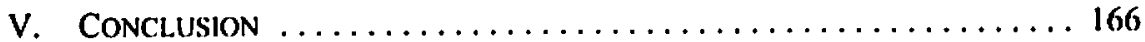

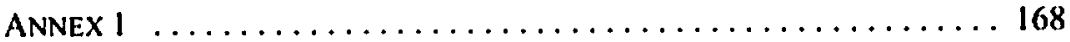

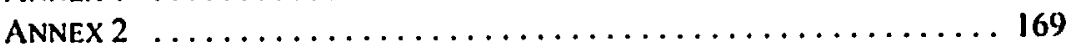

Assistant Professor, Faculty of Law, Dalhousic University. The author would like to thank Anika Rodinos for her valuable research assistance in preparing this work. 


\section{INTRODUCTION}

On 1 January 2007, the Securities Transfer Act came into force in both Ontario and Alberta.' Counterpart legislation is expected to be enacted in the other Canadian provinces.' This marks the most significant development in Canadian commercial law since the enactment of the provincial Personal Property Security Acts. ${ }^{3}$ The STA, based on Revised Article 8 of the Uniform Commercial Codet in the United States, may be classified broadly as commercial transfer of property law and governs the holding and transfer of investment securities. Through corresponding amendments to the PPSAs, it governs also the use of investment securities as collateral. The $S T A$ is drafted elegantly and readily usable and is, without a doubt, a welcome law reform initiative; modern securities settlement practice has evolved beyond a point where existing law supports it with clarity and precision. ${ }^{5}$

The legislation reflects a radical reconceptualization of property law as it applies to investment securitics. The purpose of this article is to analyze the conceptual and policy choices made by the drafters. A dominant characteristic of modern securities markets is intermediation: investment securities are held typically through a complex chain of intermediaries. The STA introduces new property law concepts to define the asset held by an investor who holds securities through an intermediary and also to define the property rights of that holder: "financial asset" and "security entitlement." It also clarifies the conflict

1 Securitics Transfer Act, S.O. 2006, c. 8 [STA]; Securities Transfer Act, S.A. 2006, c. S-4.5. All subsequent references to the STA refer to the Ontario Securities Tramsfer Act. The legislative history of (Bntario's Bill 4I. An Act w create a comprehensive system of mules for the tronsfer of securities thut is consistent with such rules across North America and to make consequemial amendments to varions Acts, is available online: Legislative Assembly of Ontario <http:/www.ontla.on.ca>; the legislative history of Alberta's Bill 36. Alherta Corporate Tar Amendment Act, 2007, is also available online: Legislative Assembly of Alberta <http:// www.assembly.ab.ca>.

2 See c.g. Bill 23, An Act respecting the Transfer of Securities and to make consequential amendments to other Acts, 3d Sess., 25th Leg., Saskatchewan, 2006-07 (assented to 17 May 2007); Bill 9, Securities Tromsfer Act, 3d Sess., 38th Leg., British Columbia, 2007 (assented to 29 March 2007), now the Securitics Transfer Act, S.B.C. 2007, c. 10. Initialives have also been taken internationally with the end of implementing law reform in this area; see e.g. Convention on the Law Applicable to Cerrain Rights in Respect of Securities /feld With an Imermediury. 5 July 2006, online: Ilague Conference on Private International Law <hipp:/www.hech.neVindex_en.php?act=conventions.texi\&cid=72> [Hague Convention]; International Institute for the Unification of Private Law (UNinkort), Preliminary Draff Comention on Substamive Rules Regarding Imermediuted Securities (as adopted by the Committe of (iovernmental Experts at its fourth session, held in Rome, 21-25 May 2007) Study LXXCIII-Doc. 94 (Rome: UNIDROIT, 2007). online: UNIDROIT <http:/www,unidmit.org/english/publications/ proceedings/2007/study/78/S-78-94-c.pdrs.

3 Sce c.g. Personal Property Secwity Act, R.S.O. 1990, c. P.10 as am. by Bill 4I, An Act to create a comprehensive system of rules for the transfer of securities that is consistent with such rules across North America and to make consequential amendmemts to various Acts, 2nd Sess., 38th Leg.. Ontario. 2006 (assented to 18 May 2006). online: Legislative Assembly of Ontario <htip://www.ontla.on.ca> [OPPSA].

- The American Law Institute, Uniform Commercial Code Revised Article 8. Investment Securities (With amendmens to drticle 9. Secured Transactions), Proposed Final Draft (Pliladelphia: American Law Instilute and National Conference of Commissioners on Uniform State Laws, 1994) [UCC].

s For a discussion of the law governing the holding and transfer of investment securities prior to the STA, see the discussion in Part III, helow.

See the discussion in Part II.B, helow.

See the discussion in Parts IV.A and IV.B, below. 
of law rules applicable to the validity and enforcement of these property rights in the context of cross-border settlement. ${ }^{8}$

Another key aspect of the $S T A$ is the codification of conveyancing and priority rules. Here also, the legislation re-articulates the principles through the introduction of additional new concepts: "control" and "collusion." In commercial law generally, disputes in the context of conveyancing require the weighing of two competing values: security of title and security of transfer. The former preserves the property rights of the prior owner as against subsequent claims to the asset in question; the latter facilitates participation in the markets by giving certain transferees precedence over prior claimants. In securities markets, disputes occur in the form of a priority contest as between the prior holder of the securities and a subsequent purchaser or secured party claiming an interest in the same securities. The balance drawn between the two competing values is, ultimately, a matter of policy.

Revised Article 8 and, by extension, the STA have been criticised both conceptually and in terms of the policy choices made. Conceptually, concerns have been raised with respect to the nature of rights held by an investor who holds securities through an intermediary..$^{10}$ This article argues that these concerns are the result of the drafting technique employed by the legislation as opposed to any substantial conceptual incoherence. The STA adopts a functional approach to drafting as opposed to a conceptual approach. This choice in drafting technique was made early in the drafting process for Revised Article 8." Despite adopting a functional approach, it is argued that the STA makes a significant contribution to the conceptual understanding of property rights in investment securities. In terms of the policy choices made, it has been asserted that the legislation favours security of transfer over security of title excessively in that property rights are not protected adequately on the basis of moral or ethical grounds. ${ }^{12}$ This aspect of the criticism will also be discussed.

This article proceeds as follows: first, an overview of traditional and modern securities settlement practice is provided to set out the context in which the STA will govern. This is followed by a background of the $S T A$ and why prior law failed to capture modern securities settlement practice adequately. The rest of the article will focus on particular issues raised by the reconceptualization of property law as it relates to securities held through an intermediary. The analysis begins with a discussion on the STA's contribution to the legal understanding of the nature of investment securities as assets and the nature of property

See the discussion in Part IV.C, below.

See the discussion in Parts IV.D and IV.E, below.

Russell A. Hakes, "UCC Article 8: Will the Indirect Holding of Securities Survive the Light of Day?"

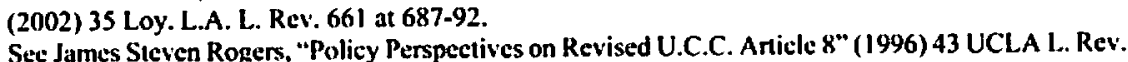
1431 at 1450 [Rogers. "Policy Perspectives"]:

The essence of the Revised Article 8 drafling technique can be stated in a few words.... The starting point of Revised Article 8 approach is to identify, in functional rather than ealcgorical lerms, what it means lo say that a person holds a security through an intermediary. The unswer to that inquiry comes in the form of the statement, in Sections $8-503$ through $8-508$, of the core of the package of rights and duties that define the relationship between a securities intermediary and a person ("entitlement holder") who holds a securities position through that intermediary.

Francis J. Facciolo, "Father Knows Best: Revised Article 8 and the Individual Investor" (2000) 27 Fla. St. U.L. Rev. 615 al 653-60. Although this discussion focuses on individual investors, the concerns are equally relevant to intermediaries holding securities indirectly through other intermediaries. 
rights in such assets. The analysis will then consider the conflict of law rules adopted by the STA that will determine the law governing the validity and effectiveness of such property rights. Finally, the conveyancing and priority rules introduced by the $S T A$ will be discussed in the context of both security interests and wrongful transfers by an intermediary.

\section{Modern Securities Settlement Practice}

\section{A. The Traditional Direct Holding System}

Securities settlement is the process by which property rights in relation to securities are transferred to perform contractual obligations entered into pursuant to a trade. ${ }^{13}$ Under a direct holding system, with registered securities, investors would have a direct relationship with the issuer in the sense that the latter would maintain a register in which the details of the investors would be entered and updated as necessary. This register would record the identities of the owners of the securities. For securities represented by negotiable certificates, ownership would be determined by possession of the relevant piece of paper. The settlement of a securities trade has traditionally involved the actual or constructive delivery of certificates as between the participants. Where a holder wished to transfer his or her interest in securities, he or she would typically endorse the certificate in blank and deliver it to the purchaser. The purchaser, in turn, would alternatively resell the securities through endorsement and delivery of the certificate or surrender the certificate to the issuer for a new one and have the register updated. An illustration of direct holding is provided in Annex 1.

Paper-based settlement involved a degree of risk in the sense that certificates were easy to lose, forge, and steal and, more importantly, it was a slow and laborious process. As the volume of trades in the securities markets increased, settlement involving the physical handling of paper became increasingly impossible. In the late 1960s, the U.S. markets experienced what became known as the "paper crunch" as the volume of business strained the settlement system to the point where the operation of the securities market was under threat. ${ }^{14}$ Today, trades on the Toronto Stock Exchange alone average approximately 236.8 million per day. ${ }^{\text {is }}$ The paper crunch arose because traditional market settlement practices could not handle the volume of trading and paved the way for electronic settlement.

The paper crunch, resulting in severe delays and disruption of the settling of trades, generated a great deal of debate in the U.S., which influenced subsequent developments in Canada. Naturally, the primary focus of the debate was the role that paper ought to play in securities settlement. ${ }^{16}$ The general consensus was to eliminate the significance of paper in the settlement of securities trades, if not eliminating the need for paper altogether and thereby

Settlement usually a lso involves the corresponding payment of the purchase price or other consideration. However, the STA focuses only on the transfer of property rights in relation to investment assets. See Alberta Law Reform Institute, Transfers of Invesimem Securilies: Reporl No. 67 (Edmonton: Albertu Law Reform Institute, 1993) at 20-24 [ALR/ Report].

The average daily trading volume is based on the volume of trades on the TSX in July of 2006. The daily average value of these Irades was approximately $\$ 5,066.1$ million: Toronto Stock Exchange, Media Releasc, "TSX Statistics - July 2006" (31 July 2006), online: TSX Group <http://www.IsX.con/en/ pdf/TSXMonthlyStats-July2006.pdis.

See e.g. Richard B. Smith. “A Piece of Paper" (1970) 25 Bus. Law. 923. 
establishing a "certificateless society." Unlike commercial law, commercial practice evolved so that whether or not securities were evidenced by paper became irrelevant. Market participants rightly recognized that the paper crunch was caused not by the mere existence of paper, but by the movement of paper needed to effect settlement. The key event in Canada signifying the trend towards paperless settlement in the securities markets was the incorporation of the Canadian Depository for Securities Ltd. (CDS) in 1970. This led to the practice known as "immobilization" and the evolution of the indirect holding system. ${ }^{18}$

\section{B. ThE MODERN INDIRECT HOLdING SYSTEM}

The indirect holding system involves the storage of certificates or instruments in a vault in order to eliminate physical movement of paper on transfer of ownership. ${ }^{19}$ This model is "widely used in global trading"20 because it alleviates the high costs arising from the issuance, safekeeping, transfer, delivery, and record-keeping processes associated with the handling of paper as well as the risks of loss, forgery, and fraud. It may involve still the use of paper associated with the issuance of securities ${ }^{21}$ and necessarily involves the use of a depository, such as CDS, in a settlement system. However, any certificates and instruments are "immobilized" in the sense that they are held by the depositary, as an intermediary, at all times. The depositary does not "own" the securities but instead may hold them for what are known as participants or for the operator of the settlement system which, in turn, holds them for participants. Participants of settlement systems are typically securities firms such as banks, brokers, and trust companies.

Although paper certificates or instruments may still exist for indirectly held securities, these certificates remain in the depositary's possession and are normally never actually delivered to participants. The issuer will typically issue a global certificate in permanent form to the depositary or its nominee. Globals may also be referred to as "jumbos" and represent an entire maturity of an issue of securities. The key implication of the use of globals issued in permanent form is that only the depository, ${ }^{22}$ not the participants, will have a direct relationship with the issuer. This is because it is only the depository that will be indicated on the register of the issuer and have possession of the relevant global certificate. The depositary will record the interests of participants as they are transferred between them from time to time by "book-entry" transfer. Book-entry transfer is a method of accounting for transfers of securities using debits and credits to electronic accounts held by intermediaries. The issuer is generally never aware of the identities or interests of these participants since its records will continue to reflect only the interest of the depositary.

U.S., Study of Unsafe and Unsound Practices of Brokers and Dealers: Report and Recommendations of the Secturities and Erchange Commission, 92d Cong., Ist Sess. (H.R. Doc. No. 92-231) (Washington, D.C.: United States Government Printing Office, 1971) at 203.

Sec ALRI Report, supra note 14 at 31-33.

19 See generally Clearance and Sethement Systems in the World's Securities Markets (New York: Group of Thirty, 1989) [1989 G30 Report].

so Roy Goode, "The Nature and Transfer of Rights in Dematerialised and Immobilised Securities" in Fidelis Oditah, ed., The Future for the Gilohul. Securities, Market: Legal and Regulatory Aspects (Oxford: Clarendon Press, 1996) 107 at 110.

3 Unless, of course, the securities are issued in paperless form.

$"$ Or its nominee. 
Access to indirect holding systems is generally restricted to established organizations as participants have to undergo an approval process based on objective criteria. ${ }^{23}$ Cross-border trading sometimes requires the use of local agents that have access to the settlement system in the jurisdiction of issue or international agents that have established a direct or indirect link to an intermediary in the jurisdiction of issue. ${ }^{2+}$ Even when not required, it may simply be more efficient as local agents would be familiar with the laws, customs, and practices of the jurisdiction of issue. ${ }^{25}$ Restricted access to participants and increased cross-border investment has necessitated the tiering of intermediaries. The participants, in turn, will act as intermediaries and will record the interests of other intermediaries or investors that hold interests in the participant's interest, also by book-entry transfer.

Intermediaries typically hold securities on an unallocated basis. In other words, the interests of all participants or investors holding interests in like securities are held together in a commingled pool or fungible bulk. ${ }^{26}$ The rights of the participants and lower-tier investors relate to securities held in a designated account rather than attaching to particular securities. Pooling all like securities in a single account results in greater settlement efficiencies by reducing the overall costs of administering and reconciling separate holdings. 27

For example, $A B C$ Limited ( $A B C$ ), incorporated under the laws of Manitoba, issues a block of $1,000,000$ shares to a depositary in Ontario (D). D would be the registered owner according to ABC's list of shareholders and the certificate for the $1,000,000$ shares issued would remain with it at all times. XYZ Brokers (XYZ), a participant of D located in Alberta, subsequently acquires 10,000 shares of $A B C$ stock of the same issue for its customers. $D$ would accordingly update its records by book-entry transfer to reflect the interest held by $X Y Z$. In turn, $C 1$, a customer of $X Y Z$ purchases 50 shares of $A B C$ stock from $X Y Z$. The remaining 9,950 shares are held in the same pool for other customers (C2). XYZ would accordingly update its records by book-entry transfer to reflect the relevant interests held by the customers. Both intermediaries, D being the upper-tier and XYZ being the lower-tier, control the securities involved in a fungible bulk. The above example of the indirect holding system is illustrated in Annex 2.

See e.g. the CDS, which currently has approximately 100 participant organizations and all those interested in becoming a CDS participant must submil an "Application for Participation" to the Board of Directors; see generally the CDS website online: <http://www.cds.ca>.

A.O. Austen-Peters, Cusiody of Invesiments; Law and Practice (Ox ford: Oxford University Press, 2000) at 17.

3) lbid. at 18.

26 "Fungible" in relation to securities may be defined as "securities of which any unit is, by nature or usage of trade, the equivalent of any other like unit": Business Corporations ACt, R.S.O 1990, c. B.16, s. $53(1)$ $[O B C A]$. All references to the $O B C A$ in this article refer to the legislation prior to the enactment of the STA. (The definition of fungible has been removed lrom the current $O B C A$ legislation and is not defined in the STA).

27 An added advantage of holding customers' securities in fungible bulk for intermediaries is that it allows them to offer services such as contractual settlement and securities lending. 


\section{BACKGround to THE UNIForm Securities TRansfer ACt ProjeCt}

In 1993, the Alberta Law Reform Institute (ALRI) published an extensive report outlining the problems of Canadian law in its application to investment securities. ${ }^{28}$ It concluded that the existing law governing the transfer of indirectly held securities had difficulties with the fact that transfers were effected by market participants electronically and that the assets of customers were held by intermediaries on an unallocated basis in fungible bulk. ${ }^{29}$ The report recommended that, due to the need for compatibility with U.S. law, Canadian provinces implement a uniform statute modelled on the then pending and now enacted Revised Article 8 of the UCC. Based on this report, the Canadian Securities Administrators (CSA) established a task force that prepared a draft Uniform Securities Transfer Act (USTA), along with corresponding draft amendments to Canadian business corporations and personal property security legislation, with a view to making it as uniform and harmonious with Revised Article 8 as possible. ${ }^{30}$ The Uniform Law Conference of Canada (ULCC) ${ }^{31}$ approved the USTA in 2004. ${ }^{32}$ As stated above, the STA received royal assent and has been in force since 1 January 2007. It is expected that counterpart legislation will be enacted in all Canadian provinces. ${ }^{33}$

Originally, investment securities were not freely transferable. Ownership was determined solely on the basis of the register maintained by the issuer. In order to facilitate trading, market participants eventually began to effect transfers by way of delivering security certificates evidencing the securities as opposed to updating the register. In 1975, this market practice was finally given official legal recognition, which resulted in a radical departure from traditional Anglo-Canadian corporate law. ${ }^{34}$ This change in the law declared that all security certificates were negotiable instruments ${ }^{35}$ except where the transfer thereof was restricted and that restriction or reference thereto was noted "conspicuously" on the

ALRI Report, supra note 14. The ALRI Report considers the legal positions in Alberta and Ontario relating to securities transfers in general. Ibid. at 2-3.

30 Ste Canadian Securities Administrators' Uniform Securities Transfer Act Task Force. Proposals for a Uniform Securities Transfer Act, Consultative Draft, 1 August 2003 (revised 4 September 2003) (Philadelphia: American Law Institute and National Conference of Commissioners on Uniform Stalc Laws, 2003), online: Ontario Securities Commission <http:/www.osc.gov.on.ca/MarketRegulation/ SpecialProjects/usta/usta_20030801_draft-comments.pdf̈̈search> [USTA Draff Proposals]. See online: ULCC <hup://www.ulcc.ca>.

32 Canadian Securities Administrators" Uniform Securities Transler Act Task Fonce: Uniform Securities Transfer Act. Approved at the Uniform Law Conference of Canada, Annual Meeting. 22-26 August 2004, (Philadelphia: American Law Instilute and Naitonal Conference of Commissioners on Uniform Statc Laws. 2004), online: ULCC <http://www.ulce.ca/en/us/Uniform_Securities_Transfer_Act_En. palP [Approved ULCC Version of USTA].

See supra note 2.

For an extensive overview of the evolution of the laws governing the transfer of share certificates in Canada, see the $A L R J$ Report, stepra note 14 at c. 4 and Bruce L. Welling. Corporate Lan in Camada: The Governing Principles. 2d ed. (Toronto: Butterworths. 1991) at 701-709.

This term is not defined in the OBCA. A negotiable instrument may be defined as "a document of tille embodying rights to the payment of money... which, by custom or legislation, is (a) transferable by delivery (or by indorsement and delivery) in such a way that the holder pro tempore may sue on it in his own name and in his own right, and (b) a hona fode transferee [for value] may acquire a good and complete title to the document and the rights embodied therein, notwithstanding that his predecessor had a defective title or no title at all": Denis V. Cowen \& Leonard Gering, Cowen on the Law of Negotiable Instruments in South Africa, 5th ed. (Cape Town: Juta, 1985) vol. 1 at 52. 
certificate itself. ${ }^{36}$ By analogy to the law of negotiable instruments, ownership of securities took the form of possession of the relevant certificate and transfers occurred by negotiation of the relevant certificate. This subsequently raised some confusion regarding the role of registration in terms of determining ownership. It had been suggested that the endorsement of a share certificate by a registered holder to a bona fide purchaser would divest the registered holder of the property in the certificate and, upon registration by the purchaser, of the shares. ${ }^{37}$ However, the ALRI Report explicitly rejected this vicw and stated that registration had absolutely no bearing on the legal ownership of the shares as assets but merely affected a holder's personal dealings with the issuer. ${ }^{38}$ The author agrees with the latter view as the change in the legislation was clearly intended to change the method of transfer from registration to delivery. ${ }^{34}$ However, this does not render the certificate as constituting the securities themselves but rather the act of transferring possession of the certificate serves merely as the procedure required for the transfer of the securities themselves. ${ }^{40}$

As described above, settlement by way of delivery resulted in the paper crunch which led to the evolution of the indirect holding system whereby investment securities are held and transferred through an elaborate multi-tiered system. Perhaps surprisingly, the $O B C A$ was the only Canadian corporate law statute to give official legal recognition to the indirect holding system." Part VI of the $O B C A$ dealt with the transfer of investment securities: s. 85 of the $O B C A$, enacted in 1986, provided that a book entry by a clearing agency, such as CDS, had the same legal effect as the endorsement and delivery of a security certificate. ${ }^{42}$ Therefore, in our example, the book entry made by $D$ to reflect the interest held by XYZ constituted a constructive endorsement and delivery of a notional certificate for 10,000 shares to $\mathrm{XYZ}$. The book entry by $\mathrm{XYZ}$ to reflect the respective interests held by its customers, however, did not similarly constitute constructive endorsements and deliveries of notional share certificates to them. This is because the deemed delivery provisions of the $O B C A$ applied only to the depositary's participants. ${ }^{43}$ The $A C$ provided that when an investor held securities through an intermediary other than a depositary and those securities formed

Sec e.g. OBCA, supra note 26. s. 53(3), as. am. by STA, supra note I. s. II0.

Welling, stupra note 34 at 725.26 .

Such as the right to vote, dividends. e'c.: see $A L R I$ Reporl, supra note 14 at $51-55$.

This accords with the recognition that securities operale in two capacities: on the one hand, they are a package of personal rights as against the issuer and, on the other, they are assets subject to property rights. The register determines the identity of the person entitled to enforce the personal rights whereas the holder in possession of the certificate determines the identity of the person who owns the securities; see the discussion in Pan IV.B, below.

See Asamera Oil Corp. Lid. v. Sea Oil \& General Corp., [1979] I S.C.R. 633 al 643, citing Rinfret J. in Vide Solloway" v. Blumberger, [1933] S.C.R. 163: "It is trite law that under the applicable statutes and common law a certificate is not in ilself a share or shares of the corporation but only evidence thereof." This may be explained by the fact that Ontario law is the law expressly chosen by CDS participants in the standard form participation agreement and virtually all securities represented in its records are held for custodians in Ontario: see Bradley Craw ford, Q.C.. "The Depesierery Bills and Noles Acr: Negotiable: Instruments for the Electronic Age" (1999) I4 B.F.L.R. 205 at 207.208. It should be noled also that similar provisions were enacted in Canadian federal legislation: see Bank Act, S.C. 1991, c. 46, s. 121: Cooperative Credit Associations Act, S.C. 1991, c. 48, s. 128; Depositony Bills and Notes Acs, S.C. 1998, c. 13, ss. 8-9; Insurance Companies Act, S.C. 1991, c. 47, s. 125; Trust and Loan Companies Act. S.C. 1991. c. 45, s. 124.

OBCA, supra note 26, s. 85(3), as rep. by STA, supra note 1, s. 118.

libid, s. 85(5). 
part of a fungible bulk, the investor was the holder of a proportionate property interest in that bulk. ${ }^{*}$ Therefore, $\mathrm{Cl}$ would have held a 0.005 percent undivided interest in the 10,000 shares held by XYZ.

Despite the $O B C A$ acknowledging the existence of the indirect holding system, its treatment of it was partial and inadequate. It was partial in that issuers of investment securities extend to non-corporate bodies such as trusts. It was inadequate in that the fictions of deemed delivery and possession do not accurately reflect market practice. In response to the paper crunch, market practice evolved to security certificates being immobilized so that the depository remained in possession of the certificate at all times. The interest of the participant is rooted in the book entry as opposed to any piece of paper, whether it be an actual security certificate in possession or a notional certificate deemed to have been transferred to the participant. Furthermore, the difference between the legal conceptions defining the interest of a holder of investment securities held through a depository and investment securities held though another type of intermediary is illogical and causes confusion. ${ }^{45}$ The problem lies in the conflation between securities and the relevant certificates. As will be discussed below, the conceptual brilliance of the STA's treatment of property rights in indirectly held securities lies in the avoidance of the tendency to conflate intangible assets with a physical manifestation. ${ }^{46}$

The above problems with the legal treatment of the indirect holding system prompted the publication of the ALRI Report and the draft USTA. The objectives underlying the draft legislation were outlined in a Consultation Paper released as part of the proposal. ${ }^{47}$ These objectives include providing a sound legal foundation for modern securities holding and transfer practices, harmonization with Revised Article 8, achicving national uniformity, and controlling systemic risk."

Providing a solid legal foundation to reflect existing market practices is one of the key objectives of commercial law, more generally. Naturally, any commercial law reform initiative has as its primary objective the alignment of law and practice, assuming there are no policy reasons to the contrary. Harmonization with Revised Article 8 is perceived as

$4 \quad$ bid., s. $78(3)$.

"s The deemed delivery provisions of the $O B C A$ in the context of indirect holding were based on the $U C C^{\circ}$ prior to the enactment of Revised Article 8 . For further criticism of these deemed delivery provisions, sec generally Charles W. Mooney, Jr.. "Beyond Negotiability: A New Model for Transfer and Pledge of Interests in Securities Controlled by Intermediaries" (1990) 12 Cardoro I. Rev. 305: Martin J. Aronstein, "The New/Old Law of Securities Transler: Calling a 'Spade' a "Heart, Diamond, Club or the Like"” (1990) 12 Cardozo L. Rev. 429: James Steven Rugers, "Negotiability, Property, and ldentity" (1990) 12 Cardozo L. Rev. 471.

th See Jeanne L. Schroeder. "Chix Nix Bundle-O-Stix: A Feminist Critique of the Disaggregation of Property" (1995) 93 Mich. l.. Rev. 239 at 315: "We Imagine an Imaginary objecl, an obje' petif a, to stand in for the Symbolic object of desire and to function as the cause of our desire. We then try to identify this Imaginary little other with something that is actually biological, natural, - - lhat is. Real. This is in the vain hope that if we attain the Real object. then our desire will be fulfilled."

4: Canadian Securities Administrators' Uniform Securitics Transfer Act Task Force. Proposal for a Ifodernized Uniform Law in Canada Governing the Holding. Transfer and Pledging of Securities. Consultation Paper (28 May 2004), online: Ontario Securities Conmission <http://www.osc.gov.on.ca/ MarketRegulation/SpecialProjects/usta/usta_20040528_consultation-paper.pdl>. 
desirable due to the level of integration between Canadian and American securities markets" and in order to maintain Canada's competitive position within North America. The need for national uniformity was alluded to above. Placing the legal rules governing securities settlement in corporate law statutes undermines uniformity at two levels. First, uniformity as between the various Canadian jurisdictions is undermined as corporate law is becoming an increasingly competitive field, thereby serving as a disincentive for uniformity. ${ }^{30}$ At a second level, uniformity as between the legal rules governing the settlement of investment securities issued by corporations and investment securities issued by non-corporate bodies is undermined. There is no principled basis to justify different settlement rules for investment securities depending on the identity of their issuer. Systemic risk may be defined as the risk that a failed intermediary will:

[C]ause a chain reaction of failures of institutions that have invested in assets held by the intermediary. Indeed, because of the international tiering of intermediaries, such a chain reaction, if it involved an intermediary holding a large enough quantity of assets, could threaten the very stability of the global financial system. 31

The principal aim of the legislation with respect to this objective is to establish a level of security for commercial transactions in the context of the indirect holding system comparable to that enjoyed under the law of negotiable instruments.

\section{ANALysis}

A complete discussion of all the proposed changes to the law governing the holding and transfer of investments securities as contained in the STA is beyond the scope of this article. The analysis below limits itself to certain key issues relating to how the $S T A$ addresses the conceptual problems of s. 85 of the $O B C A$ and attempts to capture modern securities settlement practices. A coherent framework of legal rules governing the holding and transfer of investment securities cannot be constructed without first addressing two things conceptually: the juridical substance of the asset held by a holder of securities, whether directly or indirectly, and the interest of the holder in that asset. The manner in which the asset and interest in the asset are understood conceptually will then go on to logically inform other related issues such as the rights of third parties with respect to the asset. Therefore, the analysis begins with a discussion of the STA's treatment of these two issues. This will be followed by a discussion of the treatment of conflict of law issues in cross-border settlement, the consequential amendments to the Ontario Personal Property Security Act (OPPSA) ${ }^{\text {s2 }}$ governing the attachment, perfection and priorities of security interests in investment securities, and the resolution of priority disputes in the context of wrongful transfers by an intermediary.

Approximately 20 percent of CDS's overall trading volume is now cross-border: The Canadian Depository for Stcurities Limited, taxpanding / Horizous: 2005, online: CDS Clearing and Depository Services Inc. <http://www.cds.ca/cdsclearinghome.ns/f/2ownloads/EN.AnnualReport2005/SFile/CDS annual_report_05.pdf?OpenElement> at 77. This is particularly evident in the U.S.: see generally Roberta Romano. The Genies of Americum Corporase Law' (Washington, D.C.: AEI Press, 1993). 
An underlying theme in this analysis is the contrast between functional and conceptual approaches to commercial law. More generally, this article makes the claim that conceptualism still has a useful role to play in the development of commercial law. ${ }^{53}$ It rejects the notion that adequate commercial law stems exclusively from the observation of actual commercial practices rather than from legal abstractions. ${ }^{54}$ Naturally, both approaches have their merits. A functional approach offers certainty by providing specific solutions to each question. A conceptual approach offers continuity by allowing for the resolution of new questions as new commercial practices evolve. The point here is that one may not be said to be superior categorically in relation to the other. Furthermore, even a highly functional approach requires at least some level of conceptual reasoning. ${ }^{\text {ss }}$ The challenge posed by attempting to align commercial law with commercial practice lies not in the use of concepts but in their application. More specifically, this article makes the claim that both Revised Article 8 and the STA, despite their deliberate functional approach, make a significant contribution to the conceptual understanding of investment securities in terms of their dual capacities as assets and obligations.

\section{A. The NATURE OF THE INVESTOR'S ASSET}

In order to define the legal interest of a holder with respect to an asset, one must necessarily define the asset. Investment securities have two salient characteristics, defined in terms of the legal relationships entered into by the holder. As between the holder and the issuer, the legal relationship is contractual or personal as securities represent obligations owed by the latter to the former. Issuers will need to raise capital and this is typically achieved by issuing claims against themselves to investors, such as debt or equity securities, in retum for that capital. As between the holder and the world in general, the relationship is proprietary or real as securities are assets subject to property rights. Hence, investment securities are creatures of an exceptional nature, as they, depending on the context, constitute both assets and obligations. It is the nature of investment securities as assets that is the more relevant for the purposes of the $S T A$.

Providing a precise definition for what constitutes a security as an asset is more difficult than it would first appear. Unfortunately, this is something that courts and commentators have rarely attempted. It seems that simply an intuitive understanding of what securities are

See Karl N. Llewellyn. Jurisprudence: Reulism in Theony and Practice (Chicago: University of Chicago Press, 1962) at 27: "Like rules, concepts are not to be eliminated; it cannot be done. Behaviour is too heterogeneous to be dealt with except after some artificial ordering. The sense impressions which make up what we call observation are useless unless gathered into some arrangement. Nor can thought go on without categories."

See James Steven Rogers, "Conflict of Laws for Transactions in Securities Held Through Intermediaries" (2006) 39 Comell Int'l L.J. 285 at 328 [Rogers, "Conflict of Laws"]: "One of the challenges that the [indirect holding of securities] poses is that lawyers must be willing to ahandon certain traditional concepts in dealing with these problems. For example, such shopwom phrases as "lex situs. or 'party autonomy' do not capture the issues that must be confronted in this area. Use of such phrases only obscures the real issues" [footnotes omitled].

ss See Professor Roy Goode, Commercial Law in the Next Millemmium (London: Sweet \& Maxwell, 1998) at 26 [Goode. Next Millenmium]: “[L]egal ideas, like ... any other branch of knowledge, require an organising structure, and without coneepts, principles and theories to guide them the courts would merely be reacting on a case-by-case basis to specific fact-situations, so that a ruling in one case would be no guide to the likely outcome of future disputes involving the same legal issuc." 
has, thus far, been sufficient for the purposes of making legal determinations involving securities transactions. However, the relatively recent evolution of the indirect holding system for securities has brought about some recognition of the importance in defining such assets to the legal analysis. ${ }^{56}$

In the present day, it is no longer doubted that securities are a type of transferable asset. ${ }^{37}$ They are assets simply because property rights in relation to them may be transferred from one person to another. ${ }^{5 x}$ The issue then, of course, is what exactly is the asset in relation to which property rights are being transferred? An understanding of this issue requires some introduction as to the various classifications of investment securities based on the form in which they are issued. ${ }^{59}$ With this type of classification, securities may be divided into three categories: bearer securities, registered securities, and paperless securities.

A bearer security is issued in the form of an instrument that is payable according to its terms. ${ }^{60}$ This instrument is deemed to constitute the securities by way of legal fiction; ${ }^{(1)}$ this legal fiction was designed to facilitate liquidity in the secondary markets. Hence, bearer securities are tangible assets in that they are embodied by a physical thing. They are transferred by delivery and legal ownership is determined by who has possession. A registered security is issued in the form of a certificate. However, the certificate, unlike the instrument with bearer securities, does not constitute the securities themselves but merely serves as evidence that the securities exist. ${ }^{62}$ Hence, registered securities are intangible assets in that they have no physical existence. In more recent years, issuers have begun to issue

Sec Joanna Benjamin, Interests in Securitics: A Proprietary Law Amolysis of the Imernational Securities Markets (Oxford: Oxford University Press, 2000) at 31-36 [Benjamin, Imerests in Securities); Mohamed F. Khimji, "Intermediary Credit Risk: A Comparative Law Analysis of Property Rights in Indirectly Held Securities" (2005) J. Bus. L. 287 at 289; Arianna Pretto-Sakmann, Boundaries of Personal Property: Shares and Sub-Shares (Oxford: Hart Publishing. 2005) at 61-85.

See Colonial Bank v. Whinney (1886), II A.C. 426 at 434 (H.L.), Blackburn L.J.: "There can, I think, be no doubt that shares ... though not goods in the ordinary sense of the word, are personal chattels." However, this seemingly elementary proposition was a gradual development. Historically, choses in action were not transferable at common law. Sec Colonial Bank v. Whinney' (1885), 30 Ch.D. 261 at 276-77 (C.A.), Cotton L.J. [ [ootnotes omitted], rev'd (1886), 1 ] A.C. 426 at 434 (H.L.):

undoubtedly, there has been, not only in common language but in legal language, an exlension of the application of the term, "chose in action" beyond its early meaning. Mr. Williams, Law of Personal Property. says: "In modern limes also several species of property have spning up which were unknown to the common law. The funds now afford an investment, of which our forefathers were happily ignorani" ( 1 do not read that as law). "whilst canal and railway shares, and other shares in joint stock companies, and patents and copyrights, are evidently modern sources of wealth. These kinds of property are all of a personal nature... For want of a better classification, these subjects of personal property are now usually spoken of as choses in action. They are, in fact. personal property of an incorporeal nature, and a recurrence to the history of their classification amongst choses in acrion will... help to explain some of their peculiarities."

Securities may also be classified based on the content of the obligation owed by the issuer to the holder. such as debt, equity, and hybrid securities. This type of classification is irrelevant to an analysis of securitits as assets.

A "bearer security" is defined as "[a]n unregistered security payable to the holder": Hlack 's law" Dictionan, 8th ed., s.v. "securily."

- For a brief discussion of the development of this legat fiction, sec Joanna Benjamin, Madeleine Yates \& Gerald Montagu, The Law of Global Custody, 2d ed. (London: Butlerworths, 2002) al I6-17 and the cases and commentary cited therein.

n: This point was argued above; see the discussion in Part III, above. 
paperless securities. ${ }^{63}$ These do not involve the use of either an instrument or a certificate. Naturally, paperless securities are intangible assets as they exist only by way of record keeping.

It follows that, without the aid of legal fiction, investment securities are intangible assets under a direct holding system. The settlement of a trade involving bearer securities will be effected by delivery of the instrument deemed to constitute the securities themselves. The settlement of a trade involving registered securities was effected, traditionally, by updating the issuer's register and, subsequently, by delivery of the certificate evidencing the securities. The settlement of a trade involving paperless certificates will be effected by updating electronic records. In all three categories, the common element is that the holder is in a position to enforce the obligations owed under the securities against the issuer directly. In other words, the issuer will recognize the holder of the securities as being entitled to the personal rights attaching to the securities. Ownership of the securities as assets will be established if the relevant procedural requirements are complied with, be it registration or possession. The rules governing the ownership of securities under a direct holding system are largely replicated in the new legislation. ${ }^{\text {.t }}$

As ownership of securities under a direct holding system depends on the holder's relationship with the issuer, in terms of being recorded on its register, or the holder's relationship with the certificate or instrument, in terms of being in possession, it is not particularly necessary to define the nature of securities as assets in this context. This is because the ownership of the securities as assets and the ability to enforce the personal rights against the issuer are vested in the same person. The focus remains primarily on the relationship between the holder and the issucr, this relationship being purcly personal." It is only the relationship between the holder and third parties that is proprietary."

Under an indirect holding system, however, the ultimate beneficiary of the personal rights attaching to securities is not in a position to enforce these obligations owed by the issuer directly. ${ }^{67}$ Let us go back to the example illustrated in Annex 2. D will be the registered shareholder on ABC's records and will be in possession of the certificate evidencing $1,000,000$ shares. However, D's role is merely that of a custodian for interests in the securities held by its participants, such as XYZ who holds 10,000 shares of the same issue. $D$ will maintain an account for all $A B C$ shares and record the extent of $A B C$ 's interest accordingly. $X Y Z$, in turn, maintains an account for all $A B C$ shares and records the extent of the interests of its customers, such as $\mathrm{Cl}$ and $\mathrm{C} 2$. It is only $\mathrm{Cl}$ and $\mathrm{C} 2$ that are the beneficiaries of the obligations attaching to the shares issued by $A B C$. Thus, one of the issues that the operation of the indirect holding system raises is the legal substance of the asset held

Paperless securities may be subdivided into uncertificaled securities and dematerialized securities. An uncertificated security is a registered security where no certilicale has been issued. How ever, under some corporate law statutes, a holder may compel the corporation to issuce a certificate; see e.g. OAC A, supra note 26, ss. 54-57. Dematerialized securitics, by contrast, never involse the issuance of any paper. 
by $\mathrm{XYZ}$, as a participant of a depository, and $\mathrm{Cl}$ and $\mathrm{C} 2$, as customers of $\mathrm{XYZ}$. It becomes necessary to define what exactly is owned by $\mathrm{XYZ}$ and its customers.

Economically, XYZ would legitimately expect to hold an ownership interest in 10,000 shares and $\mathrm{C} 1$ an ownership interest in $\mathbf{5 0}$ shares. Legally, upholding these ownership interests raises the difficult conceptual question of whether a legal distinction has to be drawn between the underlying securities and the asset held by $\mathrm{XYZ}$ or $\mathrm{Cl}$. Various commentators have asserted that such a distinction is necessary. ${ }^{68}$ The Official Comments to Revised Article 8, endorsed by the USTA, also state this explicitly. ${ }^{69}$ Furthermore, the STA's definition of "financial asset" appears to support this conclusion:

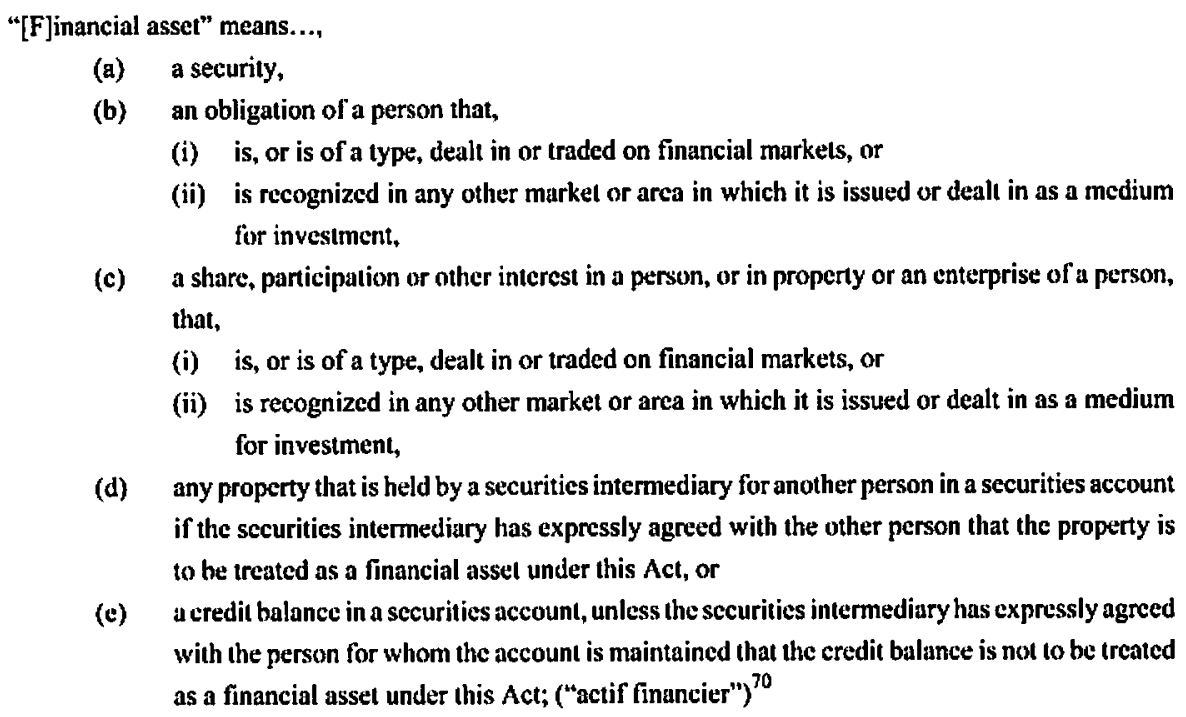

The definition seems to suggest that the asset held by $\mathrm{XYZ}$ and $\mathrm{Cl}$ is captured under clause (d) whereas the asset held by $D$ is captured under clause (a), thereby drawing a distinction between the underlying securities and "any property" held by an intermediary in an account. The STA describes the property interest of a holder of a financial asset falling

Sec Benjamin, Imerests in Securities, supra note 56 at 28-30; Austen-Peters, supra nole 24 at 73-76; Rogers, "Policy Perspectives," supra note 11 at 1455-57; Pretto-Sakmann, stupra note 56 at 56-59.

See UCC, supra note 4, § 8-110, Official Comment No. 1: "[A]n investor in the indirect holding systems has a securily entitlement, which is a bundle of rights against the securities intermediary with respect to a security, rather than a direct interest in the underlying security." The "comment" that accompanies the USTA legislation is based signilicantly on the UCC Official Comment and Prefatory Note to Revised Article 8. The STA does not make any explicit mention to the UCC Official Comment and Prefatory Note. It has been suggested that this is "perhaps because there is no precedent in Canadian legislation for giving olficial sanction to an extended interpretive gloss on that legislation provided by third parties. Nevertheless, the Comment will be an invaluable resource for self-study of the STA, and Ontario courts will no doubt turn to it for guidance in interpreting many of the legislative provisions that have no counterpart in the existing law": Robert M. Scavone, "The New Securities Transfer Act. 2005: The Coming Revolution in the Law of Securities Transfers"in Business - New Legistation: What You Don 't Know Can Hurt You (Toronto: Ontario Bar Association, 2006), onlinc: McMillan Binch Mendelsohn <http://www.mbmlex.com/Upload/Publication/RScavone_TheNewSecurities'TransferAet 2005_0106.pdi> at 14. 
under the clause (d) definition as a "security entitlement." Distinguishing between the asset held by a holder of intermediated securities and the underlying securities serves the functional advantage of limiting the holder's claim as against its own intermediary. The notion that an indirect holder's claim may be asserted only against its own intermediary was, from the outset, seen as a fundamental feature in the drafting of Revised Article $8 .^{71}$ It has been suggested that the functional advantage behind this notion boils down to the fact that the security entitlement concept is simply a more "rational"? description of the property interest held by a holder of intermediated securities:

This characteristic makes the security entitlement concept particularly competent in dealing with cross-border transactions involving muliple intermediaries. It compartmentalizes the obligations between particular entitlement holders and their securities intermediary, using privity to separate the obligations at each lier of the indirect holding system. Privity is a triad involving two parties and a system of law. With clear and certain conflict of law rules, each security entitlement can be isolated and precisely assessed for risk management purposes. $^{73}$

The notion that an investor holding securities through an intermediary does not legally own the securities has come under some criticism. ${ }^{74}$ This part of the analysis argues that this criticism is due to the unnecessary and mistaken assumption that the underlying securities have some independent existence disconnected from the indirect holder. They do not as they, being intangible assets, are purely notional. What is disconnected from the indirect holder is any personal relationship with the issuer. This, however, affects the securities in only one of the capacities in which they operate: as a package of personal rights as against the issuer. The ultimate beneficiary of these personal rights is the investor at the bottom tier of the chain, this being XYZ's customers in our example. The fact that an indirect holder has no personal relationship with the issuer has no bearing, though, on the other capacity in which securities operate: as assets subject to property rights. Should property rights in relation to indirectly held securities be enforced by either $X Y Z$ as against $D$ or $C l$ as against $X Y Z$, the asset delivered will be shares of $A B C$. The asset delivered simply cannot be anything else. In the event of an insolvency of a lower-tier intermediary such as $X Y Z$, insolvency law procedures for the processing of pre-existing property claims would ensure that all the securities entitled to it are available to meet the claims of its customers and creditors.

Furthermore, while the functional advantages to drawing a distinction between the asset of an indirect holder and the underlying securities are apparent, surcly it is not sufficient to justify a legal outcome merely on the basis of it being convenient. It must also be justified under a substantive legal analysis and in terms of its conceptual colerence. Property rights are enforceable as against the world in general, which is inconsistent with the notion that an indirect holder's property right is enforceable only as against its own intermediary. Also, the

" See Rogers, "Policy Perspectives," supra note 11 at 1455-57.

i: Erik T. Spink \& Maxime A. Pare. "The Uniform Securities Transfer Acr: Glohalived Commercial L.aw For Canada" (2004) 19 B.F.L.R. 321 at 358.

$3 \quad$ Ihid. at 359-60 [footnoles omitted].

if Set Hakes, supra note 10 at 686: "For years, those holding securities indirectly have considered themselves 'owners' of securities - having all rights and property interests in the securities. Article 8 [UCC, supra note 4, \$ 8-104, Onicial Comment No. 3] does not suppert that view, although it was 'designed to ensure that parties will retain their expected legal rights and duties"'|emphasis in original. footnotes omitted]. 
asset held by an indirect holder is indistinguishable from the underlying securities for economic, taxation, and regulatory purposes. There is no good reason to distinguish belween them for property law purposes. In the author's view, the same functional advantages outlined above may be achieved by drawing no such distinction.

The issue is not whether an indirect holder has a proprietary claim in relation to the underlying securities. The issue is to what particular underlying securities the indirect holder has a proprietary claim. For property rights to attach to an asset, the asset must be identified sufficiently. ${ }^{75}$ In the context of indirectly held securities, an indirect holder does not and cannot have property rights in relation to any securities. He or she has property rights in relation to particular securities: those in an account designated by its intermediary. ${ }^{76}$ On this basis, an indirect holder still has a claim with respect to the underlying securities, but only as against those securities in a designated account. ${ }^{7}$ Under such an analysis, the obligations at each tier of the indirect holding system are compartmentalized in a similar way, bringing the same functional advantages outlined above. ${ }^{78}$

The position that no distinction is to be drawn as between the asset held by the holders of intermediated securities and the underlying securities is also not entirely inconsistent with the definition of "financial asset" outlined in s. I of the STA ${ }^{79}$ The inclusion of the vague term "any property" under clause (d) of the definition is designed to cover financial assets held in an account that extend beyond securities in a narrow sense, such as bills of exchange or promissory notes. ${ }^{80}$ It does not necessarily draw a distinction between the asset of a holder of securities through an intermediary and the asset of a holder of securities directly from the issuer. ${ }^{81}$ This is entirely logical as an asset remains constant always and varying methods of

"S See Goode, Next Millennium, supra note 55 at 71 : "That is not simply a rule of law. it is an inescapable fact of life: I must be able to identify what I claim to own."

i6 Case law and statutory provisions support the idea that property rights may attach to an unidentified part of an identified whole. Sec Re Srapifhon Fletcher LAd., [1994] I W.L.R. 1181 at 1200 (Ch.D.). Baker J.:

In summary, on the facts here. I conclude that if a number of cases or bottles of identical wine are held, not mingled with the trading stock, in store for a group of customers, those cases or bottles will be ascertained for the purpose's of section I6 of the Sale of Cioods $A$ ct 1979 even though they are not immediately appropriated to tach individual customer. Property will pass by common intention and not pursuant to section 18, rule (5). They will take as tenants in common.

Sec also Re Goldcorp Exchange Lid. (in receivership). [1995] I A.C. 74 at 91 (P.C.), Mustill L.J.: "Their Lordships do not doubt that the vendor of goods sold ex-bulk can effectively declare himself tnustee of the bulk in favour of the buyer, so as to confer pro tanto an equitable title"; Sale of Goods Act 1979 (U.K.), 1979, c. 54, s. 20; Sale of Goods Act, R.S.B.C. 1996, c. 410 . s. 75.

$" \quad$ The STA, supra note 1 , s. $1(1)$ defines a "securities account" as "an account to which a financial asset is or may be crediled in accordance with an agrement under which the person maintaining the account undertakes to treat the person for whom the account is maintained as entitled to exercise the rights that constitute the financial asset."

For conflict of laws purposes, if follows that the sirus of indirectly held securities would be the location of the account in which such securities are held. However, this is not the approach adopted by the STA: sec the discussion in Part JV.C, below.

is See supra note 70 and accompanying text.

st) STA, supro note 1, s. 13.

"This conclusion is supported also by the corresponding amendments to the OPPSA; sec the discussion in Part IV.D.I, below. 
holding an asset affect only the nature of property rights that relate to the asset in question. ${ }^{82}$ In other words, when an investor acquires securities, the asset will remain securities of a particular class of issue in a prescribed number of units, whatever the method of holding the asset.

It is difficult to define securities as assets beyond simply as notional units of a particular class of issue. This is distinct from defining securities as obligations owed by an issuer to investors. As obligations, securities may contain myriad features such as the right to vote, the right to dividends, redemption, retraction, and convertibility. As assets, however, a particular class of securities issued is divided into units that are held by investors in various proportions. These units have no physical substance and are therefore intangible. This applies equally to bearer securities under the indirect holding system since the legal fiction deeming the instrument to constitute the securities themselves is not useful in this context ${ }^{83}$ Under the indirect holding system, units of bearer securities are transferred by book entry in the same manner as units of registered securities. The STA definition for financial asset is remarkable conceptually in that it recognizes correctly that the asset concerned comprises of purely notional units of a particular class of securities without resorting to the tendency of conflating these notional units with a physical object.

\section{B. The NATURE OF THE INVESTOR'S RIGHTS IN THE ASSET}

Having established the nature of securities as assets, the following analyzes the nature of an investor's property rights in relation to securities. Under a direct holding system, the holder has an ownership interest by virtue of being recorded as the holder on the issuer's register or by having possession of the certificate, thus having control over the disposition of the asset. Under an indirect holding system, ownership of securities and control over their disposition is separated as between the holder and an intermediary. As described above, intermediaries typically hold all like securities in a fungible bulk. This raises the question of whether the asset of a holder is sufficiently identified for the purpose of creating a property right. As explained above, one of the fundamental principles of the common law of property is that, to be able to claim ownership of a thing, one must be able to identify the thing which one claims to own. ${ }^{\text {st }}$ Failure to do so would reduce the investor's claim to the securitics to a purely personal one.

The STA recognizes the fact that an investor's interest in securities held through an intermediary relates to a bulk of securities in an account as opposed to particular securities.

32 Sce Jcanne L. Schroeder, "Death and Transfiguration: The Myth that the U.C.C. Killed 'Property"” (1996) 69 Temp. L. Rev. 1281 at 1339:

[T] he core paradigm of ... the common law... is the particular Imaginary identification of the Symbolic with the Real - the conflation of the legal right of property with an actual thing which is the object of that right and the identification of that object with tangible objects... It is not only diflicult to apply when the object of the property right is a tangible thing when the claimant does not literally have physical contact with it, but is even more troublesome when it needs to be applied by analogy when the object itself is intangible.

*1 It has been suggested that the operation of the indirect holding system negates the negotiable character of bearer securitics. See Roy Goode, Commercial Low, 3d ed. (London: LexisNexis Butterworths, 2004) at 574 [Goxde, Commercial Law]: "[l]n view of the fact that [they are] rarely, if ever, intended to be moved [their] negotiable status must be a matter of doubt." 
The new legislation creates a sui generis property interest known as a "security entitlement"; the person holding this property interest is referred to as an "entitlement holder." The technique employed in the drafting of Revised Article 8, the legislation upon which the STA is based, was to, first, describe the interest in an indirectly held security and, second, to give it a name. ${ }^{\text {} 5}$ Thus, the term "security entitlement" can be used as a shorthand for "the package of rights that a person who holds a securities position though an intermediary has against that intermediary and the property held by that intermediary." ${ }^{86}$ It is defined in s. I of STA as "the rights and property interest of an entitlement holder with respect to a financial asset that are specified in Part V1"87 of the legislation.

Part VI of the STA contains the substantive rules describing these rights. The property interest of an entitlement holder in securities held by or entitled to an intermediary is defined as being held on behalf of the former by the latter, not the property of the intermediary, and is not subject to the claims of creditors of the intermediary. ${ }^{88} \mathrm{~A}$ pro rata sharing of all like securities held by the intermediary is implied regardless of whether the interest acquired was pre-existing or forming a new part of the fungible bulk. ${ }^{8 y}$ The STA also imposes duties on intermediaries in terms of their ability to deal with the assets of their customers. ${ }^{90}$

It will be apparent that the $S T A$ does not provide a conceptual definition of what constitutes security entitlement. Instead, as is typical with modern North American commercial law, a functional and pragmatic approach is taken involving a description of simply how it works. The STA provides that a security entitlement is created when an intermediary credits or becomes obligated to credit a customer's account. ${ }^{91}$ Applying that to the example illustrated in Annex 2, $\mathrm{Cl}$ acquires a security entitlement relating to 50 units held in the account of $A B C$ shares when $X Y Z$ credits or becomes obligated to credit its account. This will not involve the transfer of 50 individual or identifiable $A B C$ shares to $\mathrm{Cl}$; instead, it will simply involve the creation of a property right held by $\mathrm{Cl}$ in relation to the $A B C$ shares in the relevant account maintained by $X Y Z$. Similarly, if $C l$ instructs $X Y Z$ to sell its 50 shares, the security entitlement held by $\mathrm{Cl}$ will be extinguished and another will be created for the purchaser. ${ }^{92}$

Although the STA uses a new legal concept representing a sui generis property interest, there are close similarities between the new legislation and some aspects of the existing common law of property. Elscwhere, it has been argued that a security entitlement simply amounts to an assimilation of the common law concept of bailment. ${ }^{93}$ In the example

Rogers, "Policy Perspectives," supra note II at 1450.

Ibid. at 1451 , citing the definition of "security entitlement" as outlined in s. 8-102(a)(17) of Revised Article 8.

STA, supra note I, s. I(1).

Jbid., s. $97(1)$.

Jbid., s. 97(2).

Jid., ss. 98-103.

Mhid., s. $95(1)$.

This will be the case if $X Y Z$ is the intermediary acting on behalf of the purchaser. If $X Y Z$ is not the intermediary acting on behalf of the purchaser, then it will have to take the necessary steps to ensure that 50 shares are delivered to the purchaser or the purchaser's intermediary.

See Khimji, supra note 56 at 308 : "The barrier preventing the law of bailment from accepting intangible property into the class of subject-matter capable of constituting the basis for such a relationship is conceptual and intellectual rather than substantive. In light of the forggoing, the control of intangible: 
illustrated in Annex 2, XYZ's security entitlement in relation to 10,000 shares in the bulk of $1,000,000$ shares held by $D$ is akin to holding an ownership interest in 10,000 shares under a bailment. XYZ's customers, being lower-tier holders, would need to rely on XYZ being able to enforce its rights against $D$ in order for there to be any assets in their designated bulk. The series of security entitlements along the chain of the indirect holding system are, thus, the equivalent of a series of related but separate bailments. They are related in that the ability of a lower-tier investor to claim its assets depends on its intermediary's ability to claim the assets it is entitled to from further up the chain. They are separate in that an investor has only a proprietary claim in relation to securities in the designated account maintained by its own intermediary. The security entitlement is remarkable conceptually in that it makes possible the separation between ownership and control over an intangible asset without the separation of legal and equitable title, a development that is long overdue. ${ }^{94}$

\section{Conflict of LAwS in Cross-Border Settlement}

Due to increasing volumes of cross-border securities settlement, another important feature of the $S T A^{95}$ is that it provides a set of conflict of law rules. ${ }^{96}$ Where the outcome of a legal dispute depends on which of several potentially applicable systems of law applies, it becomes necessary to identify the applicable law. Conflict of law rules perform this function; the rules contained in the STA will determine the law governing the validity and effectiveness of property rights in relation to financial assets. ${ }^{97}$ Under the direct holding system, the choice of law depends on whether the securities are evidenced by paper or not. For securities evidenced by or embodied in a negotiable instrument, the STA preserves the lex situs rulc generally applicable to determining the validity and effectiveness of property rights in relation to tangible assets. ${ }^{48}$ For paperless securities, the new legislation provides that the applicable law is that of the location of the issuer. ${ }^{99}$ The lex situs rule is appropriate for tangible assets, such as bearer securities, because any dealings with respect to a tangible asset will occur where the asset is located. ${ }^{100}$ Providing that the law governing the validity and effectiveness of property rights in relation to the asset will be that of the location of the asset accords with the reasonable expectation of the parties involved.

assets by means of quasi-posscssion is no different from the control of tangible assets by means of physical possession."

Sec ibid. at 307: "If the law can accommodate the custody of tangible assets while the beneficial holder still retains legal title, no logic lies behind why the same cannot be done with intangible assets. Furthermore, there is no reason why holders of interests in intangible assets should not be accorded with remedies arising from property rights as effective as those available to holders of interests in tangible assets."

For the amendments to provincial personal property security legislation, see OPPSA, supra note $3, \mathrm{~s}$. 7.

To Sec generally STA, supra note 1, ss. 44-46.

97 The conflict of law rules in the $S T A$ will also determine the law governing the obligations of partics involved in sccurities transactions. For a comparative analysis of conflict of law rules in securities Iransactions, sec generally Richard Potok, cd., Cross Border Colloteral: Legal Risk and the Conflict of Laws (London: Butterworths, 2002). STA, supra note 1, s. 46.

Ibid., s. 44(2)(d).

100 Sir Lawrence Collins et al., cds., Dicey, Morris and Collins on the Conflict of Laws, 14 ed. (London: Sweet \& Maxwell, 2006) vol. 2 at 1125. 
However, as discussed above, registered securities are not tangible assets. The STA conflict of law rules for securities evidenced by certificates in the direct holding system seem to conflate the securities with the paper associated with their issue. In the author's view, it is more appropriate to understand these rules as providing that the law governing the validity and effectiveness of property rights in relation to registered securities transferred by the delivery of paper is the jurisdiction where the paper is located. This is because the location of the paper is where any dealings in the securities will occur. The paper does not constitute the securities themselves but merely serves as an essential element to effect the procedure required for transfer. On this basis, the $S T A$ conflict of law rules for paperless securities are entirely logical as the location of the issuer is where any dealings in the securities will occur.

Under the indirect holding system, the STA, like Revised Article 8, adopts the Place of the Relevant Intermediary Approach (PRIMA). ${ }^{101}$ This approach provides that the law governing the validity and effectiveness of property rights relating to indirectly held securities is the location of the intermediary with whom an investor holds the assets. ${ }^{102}$ Such an approach follows logically from the common law position that intangible assets are located where property rights in relation to them are properly enforced. ${ }^{103}$ It is also akin to the common law principle that the sinus of registered securities held directly is the location of the register. ${ }^{\text {lot }}$ The STA sets out five simple inquiries to determine the location of the intermediary:

1. If an agreement between [a securities] intermediary and [its entitlement holder] goveming the [securities] account expressly provides that a particular jurisdiction is the [securities] intermediary's jurisdiction for the purposes of the law of that jurisdiction, this Act or any provision of this Act, the jurisdiction expressly provided for in the agreement is the [securities] intermediary's jurisdiction.

2. If paragraph $I$ does not apply and an agreement between the [securities] intermediary and [its entitlement holder] governing the [sccurities] account expressly provides that the agreement is governed by the law of a particular jurisdiction, that jurisdiction is the [securities] intermediary's jurisdiction.

3. If neither paragraph I nor 2 applies and an agreement between [a securities] intermediary and [its entitlement holder] governing the [securities] account expressly provides that the [securities] account is maintained at an office in a particular jurisdiction, that jurisdiction is the [securities] intermediary's jurisdiction.

4. If none of the preceding paragraphs applies, the [securities] intermediary's jurisdiction is the jurisdiction in which the office identified in an account statement as the office serving the entillement holder's] account is localed.

The term PRIMA was first coined by Richard Potok: see Potok, supra note 97. This approach has also gained widespread support internationally and has been adopted by the Hague Convention. The Preamble of the Convention reads. "[r]ecognising that the "Place of the Relevant Intermediary Approach" (or PRIMA) as determined by account agreements with intermediaries provides the necessary legal certainty and predictability": Hague Convention, supra note 2. is 'located' at Custodian, it is clear, as a matter of general principle, that the only proper subject of legal process by [the customer's] creditors would be Custodian." 
5. If none of the preceding paragraphs applies, the [securities] intermediary's jurisdietion is the jurisdiction in which the chicf executive office of the [securities] intermediary is located. ${ }^{105}$

The first inquiry will apply in most cases as agreements between intermediaries and their customers will typically designate a jurisdiction. In addition, the STA sets out three factors as having no relevance in determining the jurisdiction of the intermediary: the location of certificates or instruments, the location of the issuer, and the location of record keeping facilities. ${ }^{106}$ These factors are specifically excluded as they have been invoked historically by the courts as being relevant in conflict of law disputes involving securities. ${ }^{107}$

These exclusions amount to an implicit rejection of the "look-through" approach to determining the choice of law for securities transactions. The look-through approach attempts to look through securities transactions to identify each step in the holding chain and is based on the principle that the situs of investment securities is the location of where any certificate is located. ${ }^{108}$ There are both conceptual and practical difficulties with this approach. Conceptually, this approach conflates the related paper with the securities themselves when, as discussed above, certificates are merely evidence that securities exist. ${ }^{(1)}$ Furthermore, it assumes that underlying securities have some independent existence disconnected from an entitlement holder when, as argued above, they do not. ${ }^{10}$ Practically, this approach assumes that lower-tier holders of investment securities may have their property rights enforced as against upper-tier intermediaries when, in fact, this is not the case."'

It will be apparent from the rules in the $S T A$ that the drafters have favoured a pragmatic and functional approach to resolving a conflict of laws issue in dealings with investment securities. The first four inquiries in s. 45(2) look for some evidence, from either the agreement as between the investor and the intermediary or the records maintained by the intermediary, to point to the jurisdiction of the intermediary. The fifth inquiry provides the default rule where no such evidence exists and provides that the location of the intermediary is where the chief executive office is located. The most striking feature of the conflict of law rules under the $S T A$ is the law governing the validity and effectiveness of property rights in indirectly held securities may be governed by the agreement of the parties. The popular view in North American commercial law supports the notion that the lex situs rule cannot be

STA, supra note I, s. 126. These rules are replicated in the OPPSA which determines the governing law for the validity and effectiveness of security interests in investment securities: OPPSA, supra note $3, \mathrm{~s}$. 7.1(4).

STA, ibid., s. 45(3).

See generally AIRI Report, supra note 14, c. 9 .

In most cases, this would be the location of the depository. However, with paperless securities, this would the location of the transfer agent; see ALRI Report, supra note 14 at 203.

Sec the discussion in Part IV.A, above.

libid.

See Joseph H. Sonmer. "A Law ol Financial Accounts: Mexdem Payment and Securities "Transfer Law" (1998) 53 Bus. Law. 1181 at 1202 [footnotes omitled]:

[H]igher-lier intermediaries, whether banks or brokers, are under no obligation to the customers of their lower-lier account holders. They generally do not even know the identity of the lower-tier inlermediary's customers. As with higher-tier intermediaries, so with the issuer. The issuer of securities has a legal obligation to the top-tier intermediary, but no commercial-law obligations farther downstream. 
applied to intangible assets. ${ }^{12}$ This is because intangible assets have no physical existence and, therefore, cannot have a location.

An alternative approach would have been to provide a rule pointing to the location of the relevant securities account. Such a rule would make the applicable law the jurisdiction where the account is maintained and has been termed the "account-based approach." 113 The debate as between the functional rules of the STA and the account-based approach comes down to one's position on the role legal fictions ought to play in the common law legal system. In other words, is it useful to attribute notional locations to intangible assets such as accounts? The position taken by the $S T A$ is indicative of the view that it is not useful. Professor Rogers, Chief Reporter for the Uniform Commercial Code Revised Article 8 Drafting Committee, believes that the account-based approach is fundamentally flawed as an account is merely an abstract relationship incapable of having a location. ${ }^{114}$ However, in the view of the author, the account-based approach is more consistent with common law principles in that the applicable law will be synonymous with where claims to the securities would be enforced in the ordinary course. Furthermore, common law legal systems have historically invoked legal fictions to successfully deal with transfers of intangible assets by drawing analogies to tangible assets. ${ }^{\text {Is }}$ It is argued that an approach allowing the validity and effectiveness of property rights to be governed by agreement of the parties is flawed conceptually and results in functional disadvantages that do not arise under the account-based approach. ${ }^{116}$

Conceptually and logically, the law governing the validity and effectiveness of property rights in relation to assets simply cannot be determined by agreement. An agreement as between two or more parties may determine only the governing law of personal rights generated by the obligations created under the agreement. This is because personal rights are enforceable only as against the person or persons owing the obligation. However, property rights are enforceable as against the world in general, in other words, as against third parties. Therefore, an agreement as between two parties relating to an asset cannot and should not be able to affect the property rights of third parties in relation to the same asset. Conceptually, an agreement as between an intermediary and its customer may only determine

112 For example, this is reflected in the OPPSA conflict of law nules governing the validity and effectiveness of security interests in personnl property. The goveming law, generally speaking, for security interests in intangible assels would be the location of the debtor: OPPSA, supra note 3, s. 7.

113 Benjamin, Interess in Securities, supra note 56 at 160.

11 See Rogers, "Conllict of Laws," supro note 54 at 304:"An account does not have a location. Period. There is no way around that fact."

115 Sec Benjamin, interests in Securities, supra note 56 at 155: "The use of analogy has long served as a powerful technique for extending settled rules to new circumstances. This has contributed to the llexibility of the common law, which has enabled it to remain alive for a millennium. Law is a system of ideas, and provided the attribution of a situs to a claim is helpful, it matlers not that it is notional." Sec Janet Walker, Castel \& Walker: Canditon Conflict of Laws, 6th ed., looseleaf (Markham, Ont.: LexisNexis Butterworths, 2005) vol. 2 nt $\$ 22.2$.d:

More generally, where is the situs of stecuritics held through accounts with Canadian financial investment intermediaries?... In a multi-liered holding system, the account would be situaled at the financial investment intermediary on whose books the interest of the debtor appears. This is the place where the record that determines title is to be found. The place of the intermediary provides a certain, predictable and practical answer to conflict of laws questions in cross-border collateral transactions.

See also Re Bloom Estate, 2004 BCSC 70, 27 B.C.L.R. (4th) 176. 
the law governing the enforcement of obligations owed by the former to the latter. ${ }^{17}$ It may not govern the validity and enforcement of the customer's property rights in relation to the assets as these assets may be subject to competing claims by third parties.

The conceptual flaw outlined above results in the following functional disadvantage illustrated with reference to our earlier example. The intermediary, $\mathrm{XYZ}$, maintains an account consisting of 10,000 shares of $A B C$ Limited. Its customers, $C 1$ and $C 2$, hold ownership interests or security entitlements in relation to those 10,000 shares. The agreement as between $X Y Z$ and its customers indicates Ontario as the location of the intermediary. The example is then amended so that $X Y Z$ has also granted a security interest over the 10,000 shares in the same account to Finco for its own borrowings. ${ }^{18}$ The agreement as between $\mathrm{XYZ}$ and Finco indicates British Columbia as the location of the intermediary. In a priority dispute between the customers and Finco in relation to any $A B C$ shares in the account, the validity and effectiveness of the customers' ownership interest would be governed by the law of Ontario and the validity and effectiveness of Finco's security interest would be governed by the law of British Columbia. This example illustrates the risk of conflicting priority determinations under different governing laws in relation to the same asset. ${ }^{119}$

The account-based approach avoids this risk by providing for a single mandatory rule to determine the law governing all dealings in securities held in a designated account. The objections to it lie in the perceived difficulties for attributing locations to intangible assets such as accounts. ${ }^{120}$ In the author's view, these reservations may be overstated. The lex situs rule in relation to tangible assets was developed, in part, to facilitate security of transfer in commercial transactions by making it more convenient for purchasers to establish title. ${ }^{121}$ As will be evident below, security of transfer is given tremendous importance in the STA. ${ }^{122}$ The barrier preventing the application of the same rule to intangible assets is conceptual and theoretical rather than substantive; intangible assets are classified as things for the purposes of property law in the same manner as tangible assets. ${ }^{123}$ Tangible assets have a physical

117 See e.g. STA, supra note 1, s. 99 (Duty of securities intermediary re payments and distributions); s. 100) (Duty of securities intermediary to exereise rights); s. 101 (Duly of securilies internediary to comply with entillement order); s. 102 (Duty of securities intermediary re entitlement holder's direction). If the arrangement involved no cross-border clement. a secured party taking control would have priority over any entitlement holders: see ibid., s. I05.

119 Another potential difficulty with the STA's basic rule that permits the goveming law of the validity and effectiventss of property rights to be determined by agreement is the effect on third partics when a choice of law in a particular agreement is amended. The /lague Comention attempts to address this in art. 7.

130 See Rogers, "Conflict of Laws," supra note 54 at 304:

An account is an abstract legal relationship between two entilies. Abstract relationships do not have locations. Consider another old conflicts problem - whose law determines the validity of a marriage. There are many ways of resolving that problem. But there is one approach that would make absolutely no sense: decide the conllict of laws question by deciding where the marriage is located. People have locations, though they change those locations quite frequently. Events, like marriage cercmonics, take place at locations, but marriages do not have locations. Neither do accounts.

121 Gammel v. Sewell (1860). 157 E.R.1371 at 1.374, Cromplon J.

12: Sec the discussion in Pan IV.E. below.

123 See Sir Frederick Pollock \& Frederic William Maitland, The Histony of English Law: Before the Time of Elward 1. 2d ed. (Cambridge: Cambridge University Press, 1911) vol. 2 at 124-25 (footnotes omitled]:

Any permanent right which is of a transferable nature, at all events if it has what we may call a 
existence and, therefore, a factual inquiry may determine a physical location. Intangible assets have a notional existence and, therefore, a factual inquiry may determine a notional location. The fact that intangible assets are notional does not negate their classification as assets and should not negate the possibility of attributing a location to them. Furthermore, uncertainties about making an objective determination regarding the location of an account may be addressed by functional rules informed by actual commercial practices similar to those already in the STA. ${ }^{124}$

\section{SECURITY INTERESTS IN INVESTMENT SECURITIFS}

The implementation of the $S T A$ will involve consequential amendments to provincial personal property security legislation (the PPSAs). ${ }^{125}$ These amendments relate to issues peculiar to secured financing as opposed to those relating to the holding and transfer of securities, more generally. The OPPSA provisions will govem the attachment, perfection, and priorities of security interests in "investment property," a collective term including securities, security entitlements, and securities accounts. ${ }^{126}$

\section{ATTACHMENT}

Attachment may be defined as the process through which a security interest fastens itself onto an asset so as to become an enforceable property right in relation to that asset. The attachment of a security interest in investment securities requires the same three elements as any other security interest: value must be given, the debtor must have rights in the collateral, and the formalities evidencing the security agreement must be complied with. ${ }^{127}$ The first element requires a secured party to provide some consideration in exchange for acquiring property rights in relation to the collateral. The second element represents a basic principle of personal property law: property rights, in order to be enforceable, must relate to a sufficiently identified asset. ${ }^{128}$ This is reflected in the nemo dat principle that one cannot transfer greater property rights than one holds. ${ }^{129}$ Accordingly, if a debtor has no interest in a sufficiently identified asset, he or she cannot transfer an interest in that asset to a secured party.

territorial ambit, is thought of as a thing that is very like a picee of land. Just because it is a thing, it is transferable. This is no fiction invented by speculative jurists. For the popular mind these things are things. The lawyer's business is not to make them things but to point out that they are incorporcal... If we are to ketp our discussion of these things within reasonable bounds it must be devoled to that quality which they have in common. To deseribe that quality such terms as "real" and "reality" are too fecble; we must be suffered to use "thinglike" and "thinglikeness." They are thinglike rights and their thinglikeness is of their very essence. Such as specifying the location of the account as being either the location of the chier execulive oflice of the intermediary or the location of the relevant branch office.

Sece generully STA, supra note 1, ss. 123-41.

OPPSA, supra note 3, s. I(1).

Ibid., s. Il(2).

The notion of indirectly held securities being sufficiently identified so as lo vest property rights in the holder is discussed in Part IV.B, above.

It should be noted that $\mathrm{s}$. 1/(2) only requires the debtor to have rights in the collateral as opposed to full ownership: stupra note 127. A limited interest is enough to satisfy this element of attachment and, consequently, grant a security interest to the secured party: see Ronald C.C. Cuming, Catherine Walsh \& Roderick J. Wood, Personal Property Securing Law (Toronto: Inwin Law, 2005) at 164-66. 
The formalities evidencing a security agreement with respect to collateral other than investment property are either possession of the collateral or an adequate description of the collateral in a written security agreement signed by the debtor. The amended OPPSA contains separate rules as to the required level of description in security agreements where the collateral consists of investment property. ${ }^{130}$ Section 1 I(2)(a)(ii) of the amended OPPSA provides specifically that a security agreement that refers to the underlying securities is sufficient to describe assets held in the indirect holding system through an intermediary. For example, in the diagram illustrated in Annex 2, XYZ Brokers, as debtor, signs a security agreement purporting to grant a security interest in "all of the $A B C$ shares owned by the debtor." If a distinction were to be drawn between the underlying securities and the assets to which a security entitlement relates, then this collateral description would not be sufficient as XYZ would not have any ownership rights in the $A B C$ shares; such an ownership right would be held by $D$. XYZ would instead have a security entitlement with respect to the financial asset held by $D$. The new provisions serve as a recognition that market participants will continue to act as though they "own" securities held through an intermediary and that, regardless of the technical legal characterization, securitics held indirectly are, as assets, economically equivalent to securities held directly.

Attachment of a security interest in investment property may not occur by possession where the asset is intangible. Instead, the amendments to personal property security legislation introduce another key legal concept: control. ${ }^{131}$ Control may involve possession, depending on the context. This new concept will be analyzed below as it constitutes also a new method of perfection designed specifically for security interests in investment property.

\section{Perfection}

Perfection may be defined as the taking of additional steps for giving public notice prescribed by law so as to make the security interest more effective against third parties asserting a property-based claim to the same collateral. Where the collateral consists of assets other than investment property, a security interest may be perfected by possession or registration. The possibility of perfecting a security interest in investment property by possession as an alternative to registration is eliminated by the $S T A$ and replaced instead by perfection by control. ${ }^{132}$ Control may be defined simply as being in a position to dispose of the investment property. ${ }^{133}$ The precise meaning of the concept varies depending on the context. Generally speaking, it is the functional equivalent of possession in the context of the direct holding system for securities evidenced by or embodied in a negotiable certificate or instrument. ${ }^{134}$ Therefore, a security interest is perfected when an instrument or endorsed certificate is delivered to the secured party. ${ }^{135}$ With paperless securities under the direct holding system, control is obtained by the secured party when the issuer updates its register to reflect the fact that the sccured party is the holder or agrees to recognize the secured party 
as the person authorized to give instructions regarding the securities without further consent from the debtor. ${ }^{136}$

The procedure for obtaining control over security entitlements in the indirect holding system is similar to that for paperless securities under the direct holding system. ${ }^{137}$ This is achieved by either the secured party becoming the entitlement holder or the intermediary agreeing to recognize the secured party as the person authorized to give instructions regarding the securities without further consent from the debtor. ${ }^{138}$ The STA clarifies that, even where a secured party obtains control over a financial asset subject to a security entitlement, the debtor may reserve the right to otherwise deal with financial asset. ${ }^{139}$ In other words, the ability to deal with the asset need not be exclusive. This is, in substance, similar to a security interest in inventory structured as a floating charge where the debtor retains possession of collateral consisting of tangible assets.

It is evident that the legal concept of control under the STA is merely a re-articulation of long-standing commercial law principles. The concept serves as a means of identifying the party or partics that have the ability to alienate investment securities. This is akin to the notion of constructive possession. For example, where a bailee holds possession of a tangible asset for the exclusive benefit of a bailor, both parties are said to have shared possession in that asset: ${ }^{140}$ the bailee will have actual possession and the bailor constructive possession. The bailor's property right is reflective of the fact that he or she has control, in the colloquial sense, over the asset. It recognizes that, while physical possession is often necessary to establish control over a tangible object, it is not always necessary. The $S T A$, in another example of its conceptual brilliance, takes this further by taking into account the intangible nature of investment securities as assets. Physical possession may be an element of control, in the legal sense, where investment securities are certificated and settled under the direct holding system. However, as the notion of physical possession is not applicable with uncertificated securities and securities settled under the indirect holding system, the STA provides a set of rules to establish control by other means. The significant contribution made to property law by the STA, through its concept of control, is the establishment of a conceptual framework by which the separation of ownership and possession is now possible with intangible assets in the same manner that it has always been for tangible assets. ${ }^{141}$

\section{PRIORITY DiSPUTIS AS BETWEEN COMPETING SECURITY INTERESTS}

Upon the enactment of the STA, a priority contest as between two or more secured parties with interests in investment property will be governed by a set of rules that apply specifically to this type of collateral. The new priority provisions give priority to a secured party who obtains control over a secured party who does not obtain control. ${ }^{142}$ Where two or more through the law of trusts which necessitates the separation of legal and equitable title. 
secured parties obtain control under the indirect holding system, the intermediary who obtains control first in time will have priority. ${ }^{143}$ Under the direct holding system, the secured party who has control will have priority. ${ }^{144}$ Where no secured party has obtained control, priory disputes will be governed by the residual priority rules under provincial personal property security legislation. ${ }^{145}$

At first glance, the principles governing priority contests as between security interests set out above appear to be a sharp departure from the general rule in the PPSAs, being by order of perfection. ${ }^{166}$ However, these principles are analogous to the OPPSA rules governing chattel paper: ${ }^{147}$ where collateral consists of chattel paper, the OPPSA gives priority over a perfected secured party to a third party purchaser ${ }^{148}$ who takes possession in the ordinary course of its business and gives new value. Granting priority to a third party purchaser in these circumstances may be justified on the basis that, where the secured party leaves power of disposition with the debtor, it runs the risk that the debtor may in fact dispose of the collateral. ${ }^{199}$ Similarly, in the context of investment securities, if a sccured party chooses not to perfect by control, it leaves the exclusive power of disposition to the debtor. If a secured party chooses to perfect by control, it attempts to prevent the collateral from entering the market in a similar way to taking possession of chattel paper. In both cases, the debtor is prevented from granting exclusive control/possession to a subsequent secured party, thereby giving it priority.

\section{E. Priorities}

Priority disputes may also arise outside the context of security interests in investment assets, such as where securities are transferred wrongfully by an issuer or intermediary to a third party. The context of wrongful transfers by an issuer or intermediary results in two general principles of commercial law coming into direct conflict: security of title and security of transfer. The former provides that a wrongful transfer should not be effective to deprive an individual of his or her assets; the latter provides that a transfer to a good faith purchaser for value without notice should not be reversed. The STA also provides a set of rules for similar situations in the context of investment securities.

143

14

iss

140
Ihid.
/bid.
See e.g. ibid., s. 30.
Ibid., s. 30(1).

Chattel paper may be defined as a contract for the sale or lease of specific goods with a security interest taken in those goods. Chattel paper was not recognized as an asset subject to property rights under Canadian law prior to the enactment of the provincial PPSAs. The PPSAs chose to recognize it as an asset because the commercial community did so. Finance companies did take security interests in them and, therefore, the PPSA treats it as a quasi-negotiable asset. The contract itself may be used as collateral, cither under a true security interest where another secured party will take a security interest in it or under a deemed security interest where the contract will be sold to a 3rd pary: sece generally Cuming. Walsh \& Wood, supra note 129 at 389-91.

A purchaser includes a secured party. The OPPSA states that a "'purchaser" means a person who takes by purchase"; '“'purchase' includes taking by sale, lease, negotiation, mongage, pledge, lien, gift or any other consensual transaction creating an interest in personal property": OPPSA, supra note 3, s. 1(1). Jeanne L. Schroeder, "Is Article 8 Finally Ready This Time? The Radical Reform of Secured Lending on Wall Street"(1994) Colum. Bus. L. Rev. 291 at 431-32 [Schroeder, "Is Article 8 Finally Ready?"). 
The rights of a third party purchaser under the direct holding system will be addressed first. Such a purchaser is referred to as a "protected purchaser" as opposed to a good faith purchaser. A protected purchaser is defined as a person who acquires registered, bearer, or paperless securities and gives value, ${ }^{150}$ does not have notice of any adverse claims, ${ }^{151}$ and obtains control. ${ }^{152}$ Such a purchaser takes the securities free of adverse claims. ${ }^{153}$ It would, at first blush, appear that a protected purchaser does not have to act in good faith to qualify under this exception. However, s. 4(1) provides that every agreement to which the STA applies imposes an obligation of good faith on the parties in its performance.

For transfers under the indirect holding system, interestingly, the good faith purchaser for value without notice, representing a class of transferees that take free of adverse claims, was rejected by the $S T A$, like Revised Article 8 , in favour of a "collusion" standard" 154 to determine when a holder of indirectly held securities may bring an action against a party other than his or her own intermediary:

The use of the collusion test ... lurthers the interests of investors generally in the sound and efficient operation of the securities holding and settlement system. The effect of the choice of this standard is that customers of a failed intermediary must show that the transfiere from whom they seck to recover was aflirmatively engaged in wrongful conduct, rather than casting on the transferee any burden or showing that the transferee had no awareness of wrongful conduct by the failed intermediary. ${ }^{\text {iss }}$

Under the good faith purchaser doctrine, a transferee may be defeated by having either actual or constructive notice of any adverse claims. ${ }^{156}$ The prior owner of the asset has the option bringing a claim as against the transferee and will likely choose to do so as he or she will want, as a remedy, to have the asset returned. The burden of proof with respect to acting in good faith and without notice is placed on the transferec. Under the STA, an entitlement holder may not bring an action as against the purchaser unless four conditions are present: (1) the entitlement holder's intermediary has to be involved in insolvency proceedings; (2) the entitlement holder's intermediary must not have enough units of particular securities to satisfy the claims of its customers; ${ }^{157}$ (3) the entitlement holder's intermediary, when making the transfer, must have violated its obligations under $\mathrm{s} .98$ by transferring the financial asset subject to the security entitlement; and (4) the purchaser must not be protected by $5.98(7) .^{138}$

"."Valuc' means any consideration sufticient to support a simple contract and includes an antecedent debt or liability": STA, supra note I, s. I(1).

Under the legislation, ibid., s. 18, a person is assumed to have notice of an adverse claim where

(a) the person knows of it; (b) the person is aware of facts sufficient to indicate a significant probability that such a claim exists and deliberately avoids information that would establish the existence of such a claim; or (c) the person has a statutory or regulatory duty to investigate the existence of any such claims and the investigation, if carried out, would establish the existence of such a claim.

See the discussion in Parts IV.D.1 and 2, abovc; STA, ibid., s. I.

STA, ibid, s. 70.

lbid., s. 97(7). "In collusion" is delined as "in concert, by conspiratorial arrangement or by agreement for the purpose of violating a person's rights in respect ol a financial asset": ibid., s. $1(1)$.

$U C C$, supra note 4, \$8-503, Official Comment No. 3, para. 2.

May' v. Chopman (1847), 153 F..R. 1225.

An intermediary has an obligation to "maintain a financial asset in a quantity corresponding to the aggregate of all security entitlements that the securities intermediary has established in favour of its entitlement holders with respect to that financial asset": STA, supra note I, s. $98(1)$.

lbid., s. 97(4). 
Even where an entitlement holder satisfies the first three requirements, a claim as against a purchaser will be defeated if that purchaser gave value, ${ }^{159}$ obtained control, ${ }^{160}$ and did not act in collusion with the intermediary with respect to violating the latter's obligations. ${ }^{161}$ The use of the collusion standard as opposed to the good faith purchaser requirement has been subject to some criticism in the U.S. as shifting the balance unreasonably further in favour of security of title. ${ }^{162}$ The argument made generally is that it rewards dishonest transferees by placing a virtually impossible burden on the prior owner. ${ }^{163}$ This criticism will be elaborated on and evaluated below.

Conceptually, denying a prior owner the option of making a claim as against a transferee violates the principle that property rights are enforceable as against the world, in general. Also, under the collusion standard in the $S T A$, it appears that unless a transferee actively participates in any wrongdoing by the transferor intermediary, he or she will take free of any adverse claims. ${ }^{164}$ This departure from traditional property law principles is motivated by the desire for clarity in the application of the "finality principle." 165 Also, it appears to be based on the apparent confusion over the relationship between "good faith" and "without notice" 1 to6 and the "idea that discrete objects might be traced through the hands of different persons has no place in... the indirect holding system." ${ }^{.67}$ Potential concerns about the collusion standard include the requirement of both parties engaging in wrongful conduct and the apparent necessity for intentional, as opposed to negligent, behaviour. In other words, where the intermediary is negligent and the transferee has knowledge that the transfer is wrongful, an entitlement holder will not be able to establish the collusion requirement.

It is not difficult to see why this aspect of the STA may be offensive on moral and ethical grounds and it is debatable as to whether it is justified on the basis that the value of investment securities is highly dependent on liquidity. ${ }^{168}$ Al the same time, however, in the context of securities settlement, it is entirely reasonable to allow participants to assume that they are dealing with each other in good faith and requiring investigation of title prior to the settlement of every trade is unrealistic. In addition, an entitlement holder will generally only initiate a claim as against a third party in circumstances where its own intermediary will not be able to satisfy his or her claim. Furthermore, the collusion standard, like any legal standard, is impossible to articulate precisely and will be subject to judicial interpretation. There may well be little practical difference between the collusion standard and the good

194 Supra nolc 150.

too See the discussions in Parts IV.D.1 and 2, above.

1s1 STA, supra note 1, s. 97(7).

16: Facciolo, supra note 12 at 653-60.

183 See ibid. at 655 : "If the barriers to disproving a transferee as a favored purchaser would be high under [the notice requirement for the direct holding system], they would be virtually insurmountable under [the collusion requirement for the indirect holding system]."

Sec also s. I(1) of the USTA where the comment under the definition of "collusion" provides that "mere knowledge is not necessarily collusion; ... collusion requires active participation in the wrongdoing of the transferor; and that knowledge that the transfer is wrongful is a necessary but not necessarily conclusive condition of the collusion test": Approved UACC "C version of USTA, supra note 32 at 13. Rogers. "Policy l'erspectives," supra note II at 1468-73. lhid.

(s) UCC, supra note 4, \$8-503, Official Comment No. 2, para. I.

16a It has also been asserted that the collusion standard may be justified on the basis that investors will benelit from the higher prices of securities and retail investors may be protected by other means such as regulation and insurance: Schroeder, "Is Article 8 Finally Ready?," supra note 149 at 35I-56. 
faith purchaser exception as, in the author's view, courts are unlikely to uphold a transfer where the facts are so obvious as to indicate that the transferee ought to have been alerted to the possibility of wrongdoing on the part of the transferor, whether intentional or negligent. ${ }^{169}$

The proposition that tracing has no place in indirect holding deserves some comment as well. It is submitted that tracing is not about following discrete objects but is a process by which a claimant may identify substitute assets subject to his or her claim returned to the transferor in exchange for the original assets. ${ }^{170}$ In the author's view, tracing may still be a very useful process in providing remedies to defrauded holders of indirectly held securities in appropriate circumstances in terms of upholding their property rights without arbitrariness in claims as against their own intermediaries. ${ }^{171}$ It is the process of following that refers to the process of identifying the original assets as they change hands in claims as against third parties. Where the original assets are mixed with other like assets, following rules may be applied to determine the allocation of distribution among competing claimants. ${ }^{172}$ While following specific individual securities subject to prior property-based claims is impossible under the indirect holding system, it may still be possible to claim as against units of a particular class of securities in an account. The application of following rules may be useful in terms of restoring securities to an account subject to a wrongful transfer. What has to be accounted for is one of the fundamental legal principles governing following: it must be demonstrably possible, although not certain, that the units of a particular class of securities transferred wrongfully from one account were transferred to another account and that they remain in that account. ${ }^{173}$ It will not be possible to demonstrate this in most cases due to the commercial practice of clearing and netting when settling securities trades. The rare possibility of following in the indirect holding system negates the need for an excessively purchaser-friendly standard.

\section{CONCLuSion}

The STA reflects a bold rethinking of property law as it applies to investment securities. Like Revised Article 8 on which it is based, it makes a significant contribution to the

109 The shift in the burden of proving collusion under the STA is akin to the presumption of good faith under the common law in circumstances where it is not customary to investigate title. Sece Macmillan Inc. $v$. Bishopsgate Invesimem Trust (No. 3). [1995] 3 All E.R. 747 at 783 (Ch.D.), afld [1996] I All E.R. 585 (C.A.):

Unless and until they are alerted to the possibility of wrongdoing. they proceed, and are entitled to proceed, on the assumption that they are dealing with honest men. In order to establish constructive notice it is necessary to prove that the facts known to the defendant made it imperative for him to seck an explanation, because in the absence of an explanation it was obvious that the transaction was probably improper.

130 The idea of following discrete objects refers to the process of following as opposed to tracing: "this purely physical exercise is entirely different from the exercise which ... is called tracing.... Accordingly, the purely physical exercise of locating a thing is... called 'following'": Lionel D. Smith, The Law of Tracing (Oxford: Clarendon Press, 1997) at 6 [Smith, The Lons of Tracing].

17. For a concurring view, see Austen-Peters, supra nolc 24 at 76.

17. Sec generally Samucl Williston, "The Right to Follow Trust Property When Conlused Wilh Other Property" (1888) 2 Harv. L. Rev. 28; Smith, The Law of Tracing, supra note 170 at 70-91.

1". This same principle is reflected in traditional tracing rules such as the rule in Clayton's Case and the lowest intermediate balance rule: see Devaynes v. Noble: Clayton's Case (1816), 35 E.R. 781 (Ch.D.); Re Ontario Securities Commission and Greymac Credit Corp. (1986), 55 O.R. (2d) 673 (C.A.). 
understanding of property rights in relation to intangible assets and brings commercial law into the twenty-first century, where such assets will surely dominate the global economy. This contribution is made through the key definitions of "security entitlement" and "control." These definitions create a conceptual framework for property rights in intangible assets similar to that for tangible assets, thus bridging the gap between the legal treatment of the two types of assets.

This article makes the argument that, while these definitions adopt new terminology, they are similar to existing commercial law concepts but modified to reflect more accurately the fact that investment securities are intangible assets and held in fungible bulks. The conceptual advancement is made despite the functional approach adopted by the drafters. However, while the STA recognizes the possibility of intangible assets being possessed through the definition of "control," it does not recognize the possibility of intangible assets being attributed a location for the purposes of conflict of law rules. In this respect, the gap between tangible and intangible assets remains and raises potential functional disadvantages. In terms of policy, criticisms with respect to the STA's protection of property rights in investment securities, through the "collusion" standard, have been discussed. While the standard appears harsh to prior owners, it will be subject to judicial interpretation and the rare possibility of following under the indirect holding system may, in and of itself, prevent prior owners from making claims as against third parties. 
ANNEX 1

Issuer

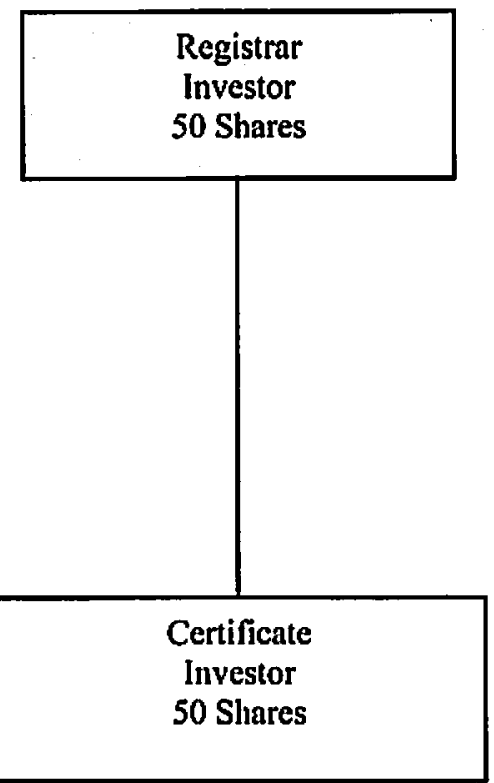

Investor 
ANNEX 2

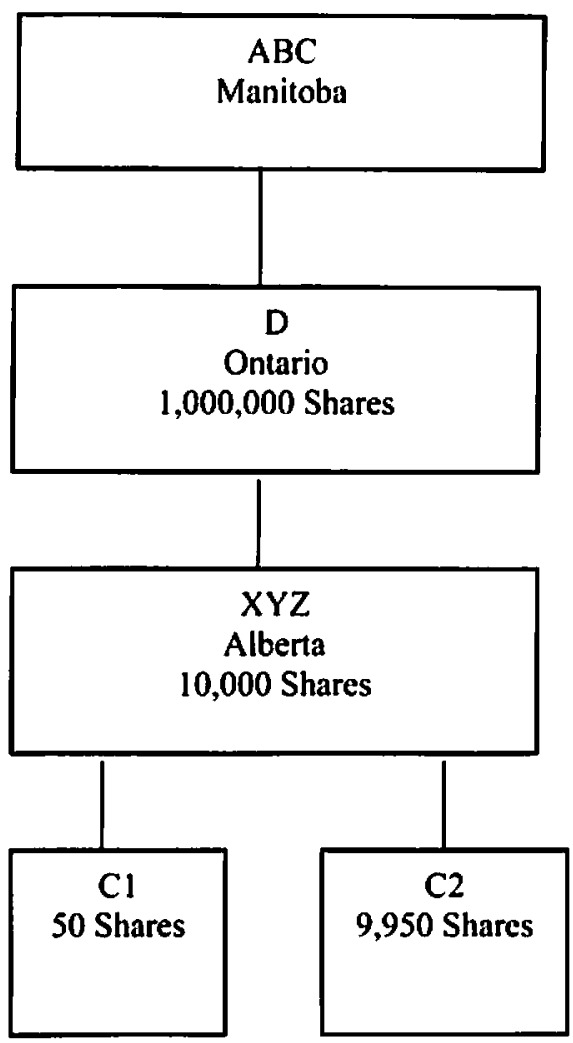

Issuer

Depository

Broker

Customer 